ISBN 978-93-84422-85-1

11th International Conference on Chemical, Agricultural, Biological and Environmental Sciences

(CABES-2018)

April 17-18, 2018 Kyoto (Japan)

\title{
Study of Horseshoe Crab as Bycatch Around Bottom Gillnet in Mayangan Waters, Subang, West Java
}

\author{
Fahresa N Supadminingsih $^{1 *}$, Mochammad Riyanto ${ }^{2}$ and Ronny I Wahju ${ }^{2}$ \\ ${ }^{1}$ Bogor Agricultural Univeristy, Jl. Agatis Kampus IPB Dramaga, Indonesia \\ ${ }^{2}$ Fishery Resources Utilization Department, Faculty of Fisheries and Marine Sciences Bogor Agricultural \\ University, Jl. Agatis Kampus IPB Dramaga, Bogor, Indonesia

\begin{abstract}
Horseshoe crab as important marine macrobentos communities which is tangled as bycatch in bottom gillnet fisheries has been poorly documented. In this study were asses the species, condition and sex ratio of horseshoe crab as bycatch in bottom gillnet fisheries at Mayangan. The observation method used by following hauling activity during August 2017. The result showed that $46 \%$ horseshoe crab catch as main bycatch. The different depth showed that $<5 \mathrm{~m}$ were dominant by Tachypleus gigas $90.4 \%$ and $>5 \mathrm{~m}$ by Tachypleus tridentatus $36.8 \%$. The condition of horseshoe crab entangled $<5 \mathrm{~m}$ was moulting shell $99.3 \%$ and $>5 \mathrm{~m}$ was maturing egg 81.8\%. The sex ratio between male: female both two different depth $<5 \mathrm{~m}$ and $>5 \mathrm{~m}$ was dominated by female 9:52 and 3:11 respectively. This information provides a baseline data to monitor the recent population to formulate the conservation strategies.
\end{abstract}

Keywords: Bycatch, horseshoe crab, condition, sex ratio.

\section{Introduction}

Bycatch is the total of non-target species or other objects caught in fishing gear operation or unwanted objects catch by fisherman [1]-[2]-[3]. Bycatch as an incidental catch in small-scale fishing operations such as gillnets contributes to the decline of marine biodiversity species effects [4]. One of protected bycatch found in commercial fisheries is horseshoe crab [5]. Tachypleus gigas, T.tridentatus and C. rotundicauda are horseshoe crab species belong to treatened status under IUCN [6] and one of protected animal in Indonesia regarding to Ministry decrees regulation No.7 year 1999 [7].

The horseshoe crab is one of Limulidae family, one of its species is Tachyphelus gigas, known as "tapal kuda" or "belangkas" or "mimi" in Indonesia [8]-[9]-[10]. In addition, horseshoe crab is one of the protected genetic resources regarding to Ministry decree of Forestry of Republic Indonesia No. 12 / KPS -II / 1987). The horseshoe crab is one of the ancient animals [8]-[10] which its existence is increasingly threatened [11]-[12]. According to reference number [13]-[5] showed the operation of gillnet for crab (blue crab) in North Carolina also catch horseshoe crab as bycatch. Nowadays, the existences of horseshoe crab as bycatch can be found in the fishing operation of the crab gillnet (Portunus pelagicus) in Mayangan waters Subang regency of West Java [14], [12].

The number of horseshoe crab caught in the fishing operation of bottom gillnet has poorly documented. The small scale fishing operation in Mayangan caught horseshoe crab in blue swimming crab net. Horseshoe crab as protected species is unmarketable fish so there was less information of horseshoe crab as bycatch. Based on that problem is necessary to quantify the proportion of horseshoe crab caught as bycatch as baseline information to determine the conservation. The purpose of this study is to know the species, conditions and sex ratio of horseshoe crab caught on bottom gillnet. 


\section{Method}

The observation was conducted at Mayangan waters, Subang regency, West Java. Mayangan was known as potential demersal fish where have relative shallow depth contour within $\pm 20 \mathrm{~m}$ with the sloping gradient. The coastal consist different morphology consists of muddy and sandy land. There were many organic materials near mangrove area which is important to nursery ground. The total observation was following the daily activity of bottom gillnetter during August 2017. The total observation ware 22 hauling processes.

The data were collected by counting the total catch and grouped into tree group of catch. The grouped catch was the main catch and bycatch (main bycatch and other incidental bycatch). The identification of the main bycatch was used to know the species, condition, and sex ratio.

\section{Results}

The total catch during the study was classified into main target and non-target, the non-target catches were grouped into protected catch and unprotected catches. The total catches were 2078 individuals, consisting of $20 \%$ (419) blue crab, 46\% (957) horseshoe crab and 34 (34\%) other catches Fig. 1

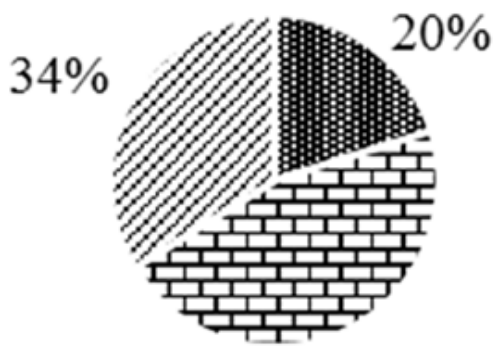

\section{\& Blue crab \\ = Horseshoe crab \\ other catches}

$46 \%$

Fig. 1: Total Catches Proportion

The average horseshoe crab species were grouped into two different depth $<5 \mathrm{~m}$ and $>5 \mathrm{~m}$. in the $<5 \mathrm{~m}$ were found $90.4 \%$ Tachypleus gigas, $70.6 \%$ Carnicoscorpius rotundicauda and 63\% Tachypleus tridentatus, while in the $>5$ m caught $9.6 \%$ T.gigas, $29.4 \%$ T.tridentatus and 36.8\% C.rotundicauda Fig.2

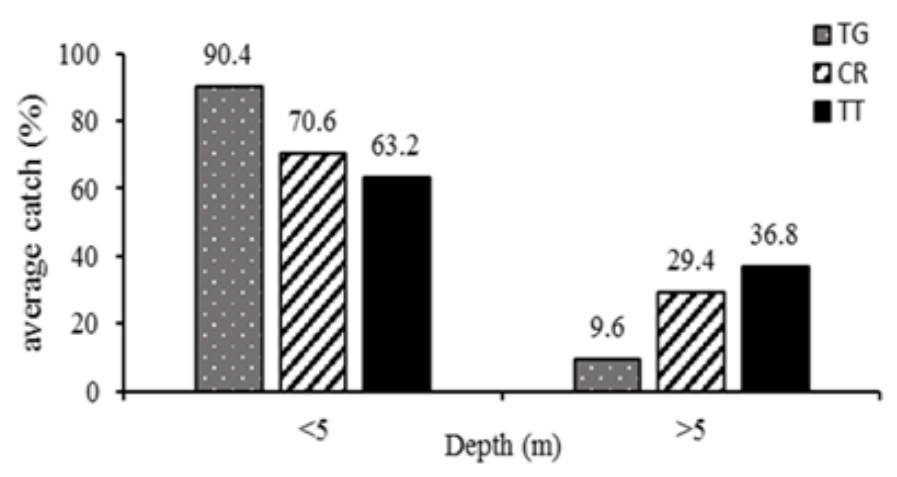

Fig. 2: Species of Horseshoe Crab in the different Depth

The average condition for all species grouped into 4 conditions in the different depth were in the normal condition in hard shell, moulting shell, maturing egg and damage by capturing. The results were similar both two area but different proportion. In the $<5 \mathrm{~m}$ the higher catch condition was dominated by moulting shell $99.3 \%$, hard shell $63 \%$ and damage condition $60.4 \%$ but less number of maturing egg $18.2 \%$. In the $>5 \mathrm{~m}$ the dominant condition were maturing egg $81.8 \%$, damage $39 \%$, hard shell $32.7 \%$ and less number of moulting $0.7 \%$ shell Fig 3. 


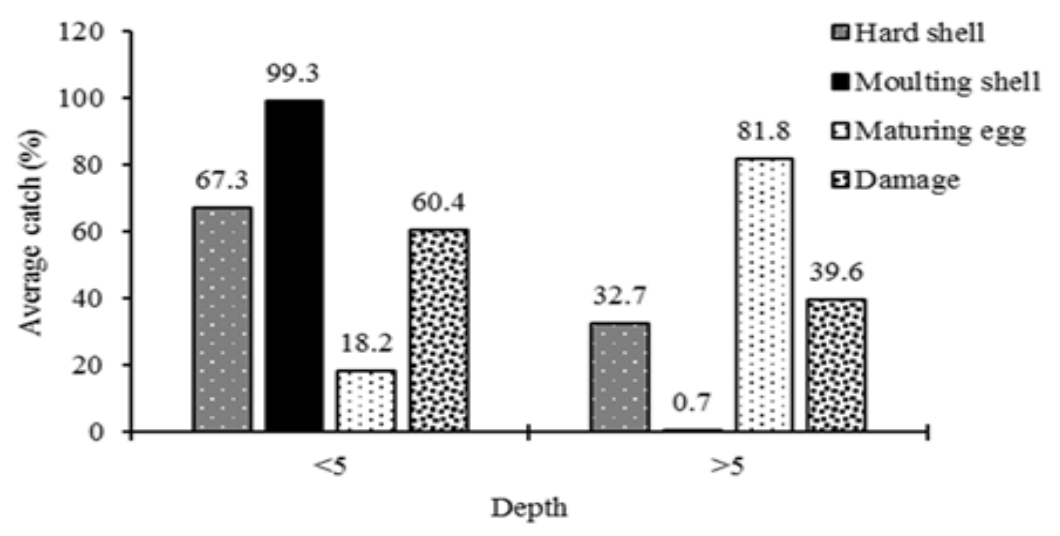

Fig. 3: The Horseshoe Crab Condition in the different Depth

The sex ratio between male and female in the $<5 \mathrm{~m}$ was 9:52 and $>5 \mathrm{~m}$ was 3:11. Female was dominant ratio between two different depth, indicated that female was the dominant sex entangled in the bottom gillnet Fig.4

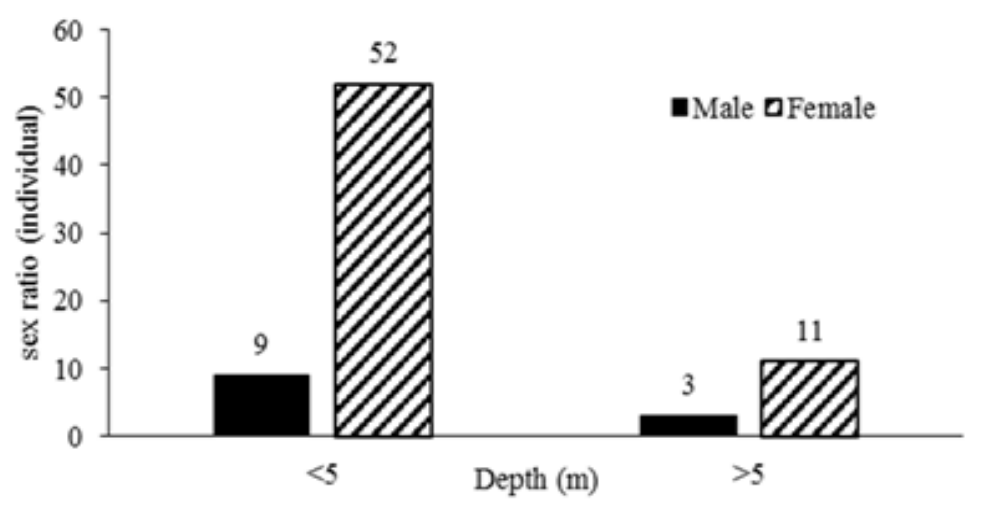

Fig.4: The Sex Ratio of Horseshoe Crab in the different Depth

\section{Discussion}

Based on previous researches, Mayangan waters is one of the potential demersal fishery areas, one of its products is crab [14]. This potential is supported by the Mayangan water still has good mangrove cover area which is used as the nursery ground. The operation of crab gillnet in Mayangan absolutely catches blue crab as the main target, but the target catch was less than horseshoe crab accordance to the proportion. According to reference number [14] as [12], Mayangan region is an area where fisherman can find horseshoe crab easily and it is often trapped in fishing nets. Another physical condition where crabs can live in an intertidal area with a distance from the coast reaching $50 \mathrm{~km} \mathrm{[4]} \mathrm{and} \mathrm{at} 24$ 0C, salinity up to $20 \mathrm{psu}$ [15].

The capture of the three Asia species of horseshoe crab at different depth indicates that the bottom gillnet operating area becomes an area which is suitable for horseshoe crab and blue crab habitat. According to reference [6] states that the high population of horseshoe crab found at 10-50 m depth from shore. The higher horseshoe crab is caught at depth of $<5 \mathrm{~m}$ among. It is suspected that horseshoe crab caught during their daily migration to the estuary and tangled in gillnet. Horseshoe crab tends to migrate to mangrove or coastal vegetation with a lagoon stretch which was available the abundant of micro-organic. After the eggs hatch, the juveniles will remain in the area near the shore and back to the sea while adult [10].

Horseshoe crab migrates to shallow from deep sea to spawn, closing to the coastal and sandy area [17]-[10]. These results were similar to the previous study [14]-[18] where the existence of 3 Asian horseshoe crab are Tachypleus gigas, T.tridentatus and C.rotundicauda can be found in the Coastal North Java and one of potential location is Mayangan. The existence of its species indicated that the Mayangan area are allows for horseshoe 
crab life and suitable to support their growth. The dominant species was T.gigas even that species in Minister of forestry decree being a protected animal but in this study found abundantly.

The horseshoe crab condition caught was dominant in moulting condition. In the $<5 \mathrm{~m}$ depth were the suitable place for horseshoe crab in moulting phase as base place for them to protect their condition from predators and high wave. In the August is the summer season where the temperature high and raise the salinity, the high salinity support horseshoe crab to increase their size by moulting. In the other hand, in $>5 \mathrm{~m}$ depth was found the higher horseshoe crab in maturing egg. The maturing crab catch can be affected by their movement, where the adult crab moves to estuary to lay their egg. The juvenile can found along the shore as their breeding place then continue the life cycle at adult in off shore then back after spawn to estuary.

The indicator to know the differences between male and female can see the appearance of the first pedipalpi. The female has the shaped leg and not bend, while the male has larger leg and claw to hook the female [19][20]-[14].The ratio between male and female indicates that's no competition among the male, so the male can choose and breeding more than one female. The higher female than the male can be affected by the decreasing of the female in maturing egg sell in the market so that the female horseshoe crab remain abundant. The higher female ratio in Mayangan was contras than in the USA, where the female harvested so the female ratio between male was fewer.

Capturing horseshoe crab as bycatch can be affected the life of horseshoe crab being injured during the capture process. The horseshoe crab injured can be a major factor of horseshoe crab die. The dredges gear contribute $6 \%$ of fish deaths are categorized as severe with some body parts missed or defects. Horseshoe crab is considered as pests for fisherman and often used as children's toys in Mayangan [12], because there is no utilization of horseshoe crab and local management regulation. Most horseshoe crabs was immediately thrown into the sea and some were released on land and dumped at the river. This is because the horseshoe crab entangled is difficult to release, need a few hour or day to release one by one, then they released on land and some of its drained and die.

\section{Conclusion}

The study concludes that the higher horseshoe crab as bycatch species caught in shallow water was T.gigas in moulting condition and female, while in the deep water the dominant bycatch was T.tridentatus, in maturity egg condition and female. The shallow water can be a conservation area involving the local fisherman, the government and stakeholder must be coordinate. Educating the fisherman and local children are important for the sustainable of horseshoe crab.

\section{Acknowledgements}

Thanks to LPDP (Indonesia Endowment Fund for Education-Ministry of Finance of Republic Indonesia) for support the study.

\section{References}

[1] R. I. Wahju, M. F. A. Sondita, S. H. Wisudo, J. Haluan, Distribution of target catch and the bycatch from small scale demersal trawl fisheries in the West Java Water, Bulletin PSP XVII, 2008, pp. 306-314.

[2] G. D. Prasetyo, R. I. Wahju, R. Yusfiandayani, M. Riyanto, Grenn Light Emitting Diode (LED) and its effect on Sea Turtle bycatch reduction of Gillnet fisheries in Paloh Waters. Marine Fisheries, 2008, vol. 8, no.1, pp.87-99, 2017.

[3] FAO, Food Agriculture Organization. 2017. A Study of the options for utilization of bycatch and discard From Marine. http://www. fao.org. [Retrieved on March 2017].

[4] H. Fazrul, S. Hajisame, M. Ikhwanuddin, S. Pradit, Assessing impact of crab gillnet fishery to bycatch population in the lower Gulf of Thailand. Turkish Journal of Fisheries and Aquatic Science, vol. 15, pp. 761-771 
[5] A. J. Bianchi, "Effects of fishing practices, gear parameters, and gear configuration on target and incidental catcth in the Southern Flouder (Paralichyths lethostigma) gillnet fishery of pamlico sound, North Carolina". North Carolina State University, pp. 1-95, 2002.

[6] IUCN, International Union for Conservation of Nature). 2016. Red list of threatened species. http://www. Iucnredlist.org. [Retrieved on Desember 2016].

[7] Government Regulation of the Republic of Indonesia. PP RI Nomor 7 Tahun 1999. 1999. Types of protected plants and animals. Jakarta

[8] M. E. Hale, Startle responses of fish without mautner neurons: escape behavior of Lumpfish (Cyclopterus lumpus). Biology Bulletin University of Chichago, Vol. 199, pp. 180-182, 2000. https://doi.org/10.2307/1542886

[9] E. L. Walls, J. Berkson, S.A. Smith, The horseshoe crab, Limulus polyphemus: 200 million years of existence, 100 years of study. Review Fisheries Sciences, vol. 10, pp. 39-73, 2002. https://doi.org/10.1080/20026491051677

[10] D.R. Smith, H. J. Brockman, M. A. Beekey, L. K. Timothy, J. Michael, Z. J. Millard, Conservation status of the American horseshoe crab (Limulus polyphemus): A regional assessment. Review Fisheries Biology Fisheries. pp. 1-4, 2016.

[11] R. Robert, A. Muhammad, P. F. Amelia-Ng, Demographics of horseshoe crab population in Kota Kinabalu, Sabah, Malaysia with emphasis on Carcinoscorpius rotundicauda and some aspect of its mating behavior. Pertanika Journal of Tropical Agriculture Science, vol. 37, no. 3, pp. 375-388, 2014.

[12] L. Meilana, Y. Wardiyanto, N. A. Butet, M. Krisanti, Morphological character and molecular identification with CO1 gene marker of horseshoe crab (Tachypleus gigas) at Coastal Waters of Northern Java Island. Jurnal Ilmu dan Teknologi Kelautan Tropis, vol.8, no. 1, pp.145-158, 2016.

[13] Muslihah, "Biologycal reproduction aspects of Mimi Bulan (Tachypleus gigas) in Mayangan waters Subang regency of West Java". 2004, unpublised

[14] I. K. Suparta, "Morphometric character of horseshoe crab Tachypleus gigas (Muller) and Carcinoscorpius rotundicauda (Latreille) in Coastal Pandeglang, West Java and Coastal Rembang, Cetral Java”. 1992, unpublished.

[15] T. C. Srijaya, P. J. Pradee, A. Hassan, A. Chatterji, F. Sharharom, J. Andrew, Colour preference and light sensitivity in trilobite larvae of mangrove horseshoe crab, Carcinosscopius rotundicauda (Latreille 1802), Indian Journal Experimental Biology, vol. 52, pp. 281-190, 2015.

[16] Cartwrigth-Taylor, Study of Horseshoe crab around Singapore: In Changing global perspective on horseshoe crab biology, conservation and management chapter 10, 2015.

[17] M. B. Mulya, "Preservation of genetic resources of Mimi Ranti (Carnicoscorpoius rotundicauda L) and Mimi Bulan (M)”. 2004, unpublished.

[18] A. Mashar, N. A. Butet, B. Juliandi, Y. Qonita, A.A. Hakim, Y. Wardianto, "Biodiversity and distribution of horseshoe crabs in Northern Coast of Java and Southern Coast of Madura," in Proc. Earth and Environmental Science IOP Conference Publishing, 2017.

https://doi.org/10.1088/1755-1315/54/1/012076

[19] R. L. Koptal, S. K. Agarwal, R. P. Khetarpal, Modern text book of zoology. Ivertebrate Kastongi Publication India, pp. 511. 1981.

[20] T.E. Bowman, Horseshoe crab in the Encyclopedia America International Education. American Corp, pp.14:430, 1977. 